\title{
2 Samuel 12 as retold by Josephus
}

C T Begg

(Catholic University of America, Washington, DC)

\section{ABSTRACT}

\section{Samuel 12 as retold by Josephus}

In this essay the author intends to focus on Josephus' retelling of the events of 2 Samuel 12. At the opening of his Antiquities, Josephus assures readers that in what follows he will not "add to" or "omit anything from" the Scripture records on which he is basing himself. Ant. 7.147-161, where on the one hand the basic content of 2 Samuel 12 is reproduced even in its details, while on the other additions, deletions, re-arrangements and other modifications of biblical data abound, offers an instructive example of how seriously, but also how flexibly, the historian carried through on that opening promise.

\section{INTRODUCTION}

2 Samuel 11:27b $\beta-12: 31$ relates a dramatic series of events: the confrontation between David and Nathan, the death of David's first child by Bathsheba and the birth of the couple's second child, Solomon, and the subjugation of Rabbah of the Ammonites ${ }^{1}$. In this essay, I wish to focus on Josephus' retelling of the events of 2 Samuel 12 in his Antiquitates judaicae (hereafter Ant.) 7.147-161' ${ }^{2}$ I undertake my comparison of the two passages with three overarching questions in mind. First, given the differences among the various ancient witnesses to the text of 2 Samuel 12 itself, i.e. MT (BHS), 4QSam ${ }^{\mathrm{a} 3}$, the Codex Vaticanus (hereafter B) ${ }^{4}$ and the

1 Like many commentators, I take the concluding words of 2 Samuel 11:27 ("but the thing that David had done displeased the Lord") as belonging more with the following chapter 12 as its introduction than with the preceding story of chapter 11 . Nevertheless, in this essay I shall speak of 2 Samuel 12 as a shorthand way of referring to $11: 27 \mathrm{~b} \beta-12: 31$. Among recent treatments of 2 Samuel 12 (and its preparation in 2 Samuel 11), see Nutkowicz (2004:104-18).

2 For the text and translation of Ant. 7.147-161, I use Marcus (1934:438447). I have likewise consulted the older text of the passage in Niese (1955:122-125) and the more recent text and translation of Nodet (2001:162167).

3 For the text of 2 Samuel 12 (partially) preserved in 4QSam ${ }^{\text {a }}$, I use Finke (2001:199-206) and for the translation Abegg, et al (1999, 245-246). 
Antiochene or Lucianic (hereafter L) manuscripts ${ }^{5}$ of the LXX, the Vetus Latina (hereafter VL) ${ }^{6}$, the Vulgate (hereafter Vulg. $)^{7}$, and Targum Jonathan of the Former Prophets (hereafter Tg.) ${ }^{8}$, where do Josephus' textual affinities in Ant. 7.147-161 lie? Second, what kinds of rewriting techniques does the historian bring to bear on the data of 2 Samuel 12 and what is distinctive about his version that results from their application? Finally, how does Josephus' handling of 2 Samuel compare with other ancient Jewish and Christian treatments of the chapter?

For purposes of my comparison I divide up the material of 2 Samuel 12 and Ant. 7.147-161 into five parallel segments: 1) Nathan Dispatched (11:27b $\beta-12: 1 \mathrm{a} \alpha / / 7.147 \mathrm{a})$; 2) First Exchange between Nathan and David (12:1aßb-6// 7.147b-150a); 3) Second Exchange between Nathan and David (12:7-15a// 7.150b-153); 4) Death and New Birth (12:16-25// 7.154-158); and 5) Rabbah Conquered (12:26-31// 7.159-161).

\section{NATHAN DISPATCHED}

2 Samuel 11:27b $\beta$ sets in motion all that follows with its laconic theological comment on David's deeds as related in the whole

4 For the B text of 2 Samuel 12 I use Brooke, MacLean and Thackeray (1927:140-144). B 2 Samuel (Reigns) 12 is part of one of the two "kaige segments" of Reigns in B, i.e. 2 Rgns 11:2-3 Rgns 2:11; 3 Rgns 22:1-4 Rgns 25:30, which have undergone a more thorough-going assimilation to the text of (proto-) MT than have its "non-kaige segments" (1 Rgns 1:1-2 Rgns 11:1; 3 Rgns 2:12-3 Rgns 21:43). On the subject, Barthélemy (1963:34-41, 91-143).

5 For the Antiochene/ L text of 2 Samuel 12, I use Marcos and Saiz (1989:118-122).

6 For the (fragmentary) VL readings of 2 Samuel 12, I use Sabatier (1751) and Rodríguez (1989:41-42).

7 For the Vulg. text of 2 Samuel 12, I use Gryson (1994: 431-433).

8 For the targumic text of 2 Samuel 12, I use Sperber (ed) (1959:177-179) and for the translation of this Harrington and Saldarini (1987:180-181).

9 For a survey of the Nachleben of 2 Samuel 12 in Jewish and Christian tradition, see Wojcik (1980:13-35).

102 Samuel 12:26-31 has a (partial) parallel in 1 Chronicles 20:1b $\beta-3$ that differs in many particulars from the Samuel account of Rabbah's overthrow. As is well-known, the Chronicler simply omits the entire embarrassing narrative of 2 Samuel 11:2-12:25 with its portrayal of David's sin and its painful sequels. 
preceding chapter: "But the thing that David had done displeased the Lord". Josephus' version accentuates (6.147a) the divine displeasure: "God, however, did not look upon this marriage with favor, but was angry $\left(\delta \iota^{\prime} I \ddot{\rho} \rho \gamma-\zeta \S \chi \omega \mathrm{v}\right)$ with David...". The Lord forthwith acts on his displeasure by "sending" Nathan to David according to 2 Samuel 12:1a $\alpha$. Josephus dramatizes the Deity's (7.147b) inter-

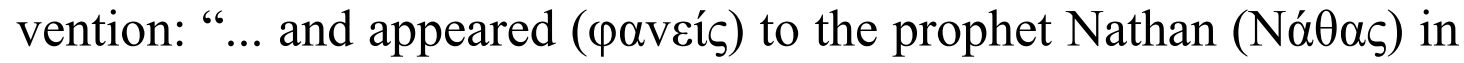

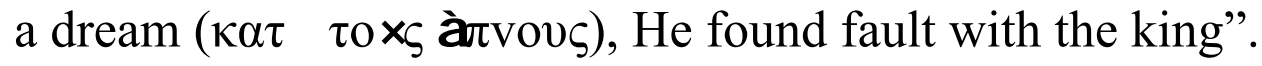

\section{FIRST EXCHANGE}

Having been "sent" by God (2 Sam 12:1a $\alpha$ ) the biblical Nathan proceeds immediately to address David with his famous parable $(12: 1 \mathrm{a} \beta \mathrm{b}-4)$, to which the king then responds at length in 12:5-6. Between dispatch and parable, the historian interjects (7.147b) an extended explanation as to why Nathan chose to address David's in the highly indirect way he does. The explanation reads:

Thereupon Nathan, being a man of tact and understanding $(\bullet \sigma \tau \varepsilon 10 \varsigma \kappa \alpha \hat{A} \sigma u v \varepsilon \tau o ́ \varsigma)$, and reflecting that when kings fall into

11 On Josephus' virtually complete avoidance of the biblical title "Lord" (LXX Kúpios) for the Deity, given, it would seem, its non-currency in secular Greek in that usage, see Begg (1993:45, n. 218).

12 With this term Josephus specifies what "the thing" that evoked God's displeasure according to 2 Samuel 11:27b $\beta$ in fact was.

13 Josephus' use of this title for Nathan has a counterpart in a few Hebrew MSS, as well as in LXX BL 2 Samuel 12:1. The title lacks an equivalent in MT.

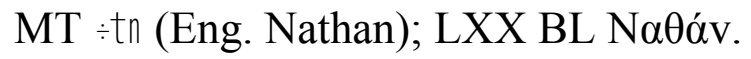

14 Elsewhere as well, Josephus introduces mentions of (dream) "appearances" by the Deity to a human figure in contexts where the Bible does not do so. On the phenomenon, see Begg (1993:53-54, n. 300). On Josephus' "dream accounts" overall, see Gnuse (1996:129-272).

152 Samuel 12:1a $\alpha$ simply mentions the fact of God's "sending" Nathan to David, with no indication of what he told the prophet about the king's case when doing so. Josephus' Deity makes clear to Nathan what he thinks of David's actions.

16 This is Josephus' only use of this collocation. His two remaining utilizations of the term $\bullet \sigma \tau \varepsilon \tilde{A}) \varsigma$ are in Ant. 9.26 and 12.177. 
passion ( $\varepsilon \not \mathcal{E} I \ddot{\rho} \rho \gamma \eta \dot{v})$ they are more influenced by this than by a

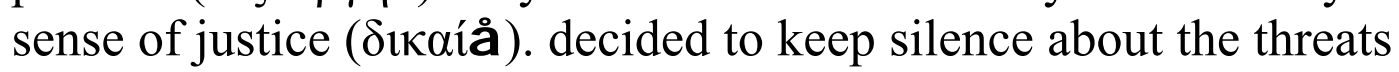
that had been made by God, and instead addressed him in mild terms, and somewhat in the followed manner, asked him to give him his opinion of a like case....

Nathan's parable opens in 2 Samuel 12:1b-3a $\alpha$ with a presentation of its two characters, one rich, the other poor, and their respective possessions. Josephus' rendition (7.148) reproduces this opening sequence with insignificant modifications: "There were", he said, "two men living in the same city, one of whom was wealthy and possessed many herds of beasts of burden, sheep and cattle, while the other had only one ewe lamb". MT 2 Samuel 12:3aßb lists no

17 This phrase echoes the use of the construction $\delta t^{\prime} \ddot{I} \rho \gamma-\varsigma \S \chi \omega \mathrm{v}$ in reference to the Deity in 7.147a. David's fall into Ï $\rho \gamma \eta$ evokes God's own Ï $\rho \gamma \tilde{~}$ against him.

18 Words of the $\delta 1 \kappa-$-stem occur repeatedly in Ant. 7.147-161; see 7.150, 152(bis).

19 The above sequence lacks a counterpart in 2 Samuel 12; it takes the place of the allusion to Nathan's coming to David in 12:1aß. (I italicize such elements that are peculiar to Josephus' presentation in this essay). The whole formulation serves as a lead-in to the historian's version of a "plus" of LXX L 2 Samuel 12:1b that there serves to introduce Nathan's telling of his parable in $12: 1 b-4$, i.e. "tell me your judgment on this". See next note.

20 On this opening request by Nathan to David as Josephus' version of the LXX L plus in 2 Samuel 12:1b, see previous note. In rendering that element Josephus turns its direct address ("tell me your judgment of this") into indirect; on this frequent feature of Josephus' rewriting of the Bible, see Begg (1993:38). In his version of Nathan's actual parable in what follows, Josephus will, however, retain the source direct address.

212 Samuel 12:2 ascribes "very many flocks and herds" to the rich man. "Josephus magnifies his wealth by making him the owner of "beasts of burden" as well. He likewise combines into a continuous sequence the biblical data $(12: 1 \mathrm{~b} \beta, 2)$ concerning the rich man which biblically are separated by the introduction of the poor man at the end of $12: 1 \mathrm{~b} \beta$.

22 From the presentation of the poor man in $12: 1 \mathrm{~b} \beta, 3 \alpha \alpha$, Josephus omits various minor details: the explicit characterization of him as "poor", the qualification of the lamb as "little", and the notice that the man had "bought" this. 
less than six indications of the poor man's attachment to his lamb. Josephus (7.149a) reduces this catalogue to three items, each a variation of some element of the biblical list (see n. 24): "This he brought up with his own children, sharing his food with it, and giving it the same affection ( $\varphi$ i $\delta \tau$ $\left.0 \rho \gamma i^{\prime \prime}\right)$ that one would give one's own daughter".

Nathan's parable concludes in 12:4 with a precipitous series of events: the arrival of the rich's man visitor, the former's unwillingness to use any of his own livestock to feed the latter, his taking the poor man's lamb, and serving this to his caller. Josephus continues to follow the biblical wording quite closely here (7.149b): "Now once, when the wealthy man was visited by a guest ( $\xi \dot{\varepsilon}$ vov), he did not see fit to slaughter one of his own animals for the feasting of his friend ( the poor man, and prepared it for the delectation of his guest".

The biblical account of David's response to Nathan's parable opens in 2 Samuel 12:5a with mention of the king's "anger being

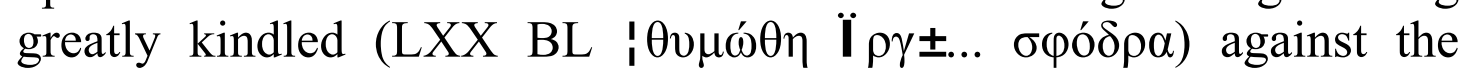
[rich] man". The Josephan parallel (7.150a) reports a different emotional reaction on David's part: "This story greatly distressed ( $\left.\sigma \varphi o ́ \delta \rho \alpha . . \mid \lambda v^{\prime} \pi \eta \sigma \varepsilon v\right)$ the king...”. 2 Samuel 12:5b-6 reports David's commentary on the prophetic story, this consisting of an oath

23 "He brought it up, and it grew up with him and his children; it used to eat of his morsel, and drink from his cup, and lie in his bosom, and it was like a daughter to him". BL LXX add an additional initiative at the opening of the list, i.e. "he watched over it".

24 Josephus concludes his list with a formulation that spells out (and intensifies) the meaning of the final words of 12:3, i.e. "and it [the lamb] was like a daughter to him".

252 Samuel 12:4 calls the rich man's visitor a "traveller". In assigning the latter the status of both a "guest" (this term has a counterpart in the VL reading in 12:4, i.e. hospes) and a "friend", Josephus accentuates the inexplicable mean-spiritedness of the former who is unwilling to use even one of his many beasts to provide for a "guest-friend".

26 According to $12: 4$ the rich man took the lamb himself. Josephus' wording offers a more plausible scenario: occupied as he was with receiving his "friend", the rich man dispatched retainers to seize the lamb.

27 The $\lambda v \pi \eta$-stem constitutes a Leitwort in Ant. 7.147-161; see 7.153,156, 158. 
formula, a double sentence on the rich man (condemnation to death and to fourfold [so MT/ sevenfold, LXX] restitution for the lamb), and two-part motivation of the sentence (the man's having "done this thing" and "shown no pity"). Josephus (7.150b) re-arranges, abbreviates and otherwise modifies this sequence: "... and he declared to Nathan that the man who had the heart ( $\left.{ }_{1} \tau o ́ \lambda \mu \eta \sigma \varepsilon v\right)$ to do

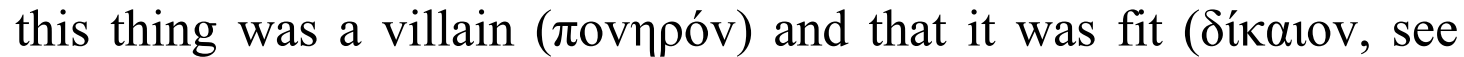

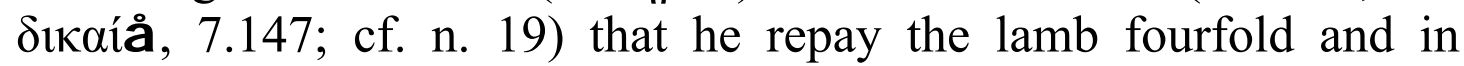
addition he be punished with death".

\section{SECOND EXCHANGE}

The story related in 2 Samuel 12 reaches its climax in the second, much more personal, exchange between Nathan and David of vv. 715a (// 7.150b-153), wherein the prophet delivers a judgment speech against the king (vv.7-12), the king responds with a penitential confession (v. 13a), which itself evokes an announcement of a (partial) reprieve from Nathan (vv. 13b-14a), who then returns home (v. 15a).

28 In line with his standard practice Josephus omits David's opening oath formula ("as the lord lives") of 12:5b. His procedure in this regard might reflect a concern to avoid any possible misuse of the divine name by his characters (and ultimately by himself, the author).

29 The above affirmation by David might be seen as Josephus' anticipation and adaptation of the double motivation for the sentence upon the rich man (12:6a) which the king ends his words to Nathan in 12:6b: “... because he did this thing, and because he showed no pity". Josephus has David pronounce an explicit moral evaluation of the rich man - an ironic touch given the king's own egregious crimes.

30 This specification concerning the extent of the prescribed restitution agrees with that laid down by David in MT 2 Samuel 12:6a (and some LXX L MSS) - which itself parallels the prescription of Exod 21:37 that the one stealing a sheep is to repay "fourfold". In LXX BL* 12:6 David prescribes "sevenfold" restitution, this likely reflecting Prov 6:21 (the thief has to pay "sevenfold"). According to b. Yoma 22b with his demand for "fourfold" restitution, David unwittingly foreshadows the four personal tragedies among his children he will experience during his lifetime, i.e. those of the first child borne to him by Bathsheba, Amnon, Tamar, and Absalom.

31 Josephus reverses the "anticlimactic" sequence of 12:6a where the lesser penalty of restitution is mentioned by David subsequent to his having pronounced the ultimate sentence of death upon the rich man. 
Nathan initiates his words against David with the blunt declaration, equating the king with the rich man he has just condemned to death, of 12:7aa: "you are the man (+ who did this, LXX BL)". Josephus (7.150b), in the line of the LXX plus, expatiates on the biblical prophet's laconic (two words in Hebrew) retort: "Nathan thereupon rejoined that David himself was the one who deserved this punishment, having been condemned by himself

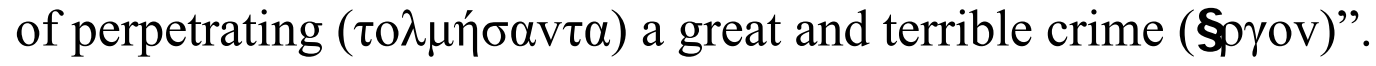

Nathan's indictment of the king continues in $12: 7 \mathrm{a} \beta \mathrm{b}-8$ where he reminds David of God's multiple past benefits to him. The historian (7.151a) prefaces this enumeration with an introductory statement concerning the divine displeasure towards the king: "He also revealed to him in the plainest fashion the wrath of God $(\tau \neg \mathrm{v}$ Ï $\gamma \gamma \eta \dot{v} \tau \varnothing \varnothing \theta \varepsilon \circ \varnothing$, for though he had made him king of all the Hebrew host and lord of all the many great nations around them, and

32 Nathan's response as formulated above ironically echoes David's own outraged language regarding the rich man in $7.150 \mathrm{a}$; see his allusion to the

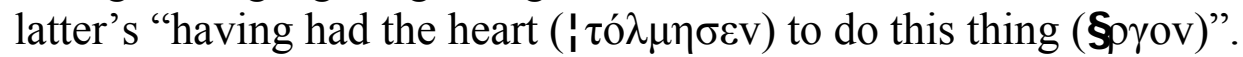

33 This phrase echoes the mention of God's "being angry" ( $\delta \iota^{\prime}$ ï $\left.\rho \gamma-\zeta \S \chi \omega \mathrm{v}\right)$ with David in 7.147a. Earlier (see 7.147b), Nathan chose not to disclose that divine "anger" to David; now he does so in "plainest fashion". The above opening of Nathan's word takes the place of the "messenger formula" ("thus says the Lord, the God of Israel") used by him in 12:7a $\beta$ which Josephus invariably avoids. The historian likewise recasts the entirety of Nathan's direct discourse speech of 12:7-12 in indirect discourse; see n. 21.

34 This particle serves to make the following list of divine benefits that David has treated so abusively the motivation for the "wrath of God" towards him that Nathan has just announced to the king.

35 The list of divine benefits in $12: 7 \mathrm{~b}$ begins with the reminder "I anointed you king over Israel", the allusion being to Samuel's doing this at God's behest to the boy David in 1 Samuel 16:13. Here, as often elsewhere, Josephus rewords biblical anointing/Messiah language out of deference to Roman sensibilities on the subject of contemporary Jewish messianism; see Feldman (1998a:554-555).

36 In 12:7b $\alpha$ David is anointed king “over Israel". On Josephus' use of the term "Hebrew(s)" for his people at various moments of their history and in comparison to other such designations ("Jews, Israelites") employed by him, Harvey (1996:124-129). 
had, even before that, delivered him from Saul's hands, and had given him wives to take in rightful and lawful marriage...".

In 2 Samuel 12:9-10 Nathan proceeds to excoriate David for the crimes he has committed, notwithstanding the divine benefactions cited in 12:7a $\beta-8$. The accusations begin 12:9a $\alpha$ with the prophet asking why David has "despised the word of the Lord (so MT LXX B; in LXX L [cf. VL] David is charged with despising the Lord himself)". Josephus' version (7.151b) aligns itself with LXX L's formulation of the charge, even while turning its reproachful question into an affirmation by the prophet: “... yet $\mathrm{He}$ had been disregarded and impiously treated $(\bullet \sigma \varepsilon \beta \eta \theta \dot{\varepsilon} v \tau \circ \varsigma)$ by him...". Nathan's denunciations become more concrete in 12:9a $\beta \mathrm{b}$ where he (twice) accuses David of having killed Uriah "with the sword", a mention of his appropriation of the victim's wife supervening. Josephus eliminates the duplication of the murder charge and reverses the order of the two accusations: “... when he

37 This extension of David's realm beyond "Israel" itself (so 12:7b $\alpha$ ), has in view David's subjugation of various neighboring peoples as described in 2 Samuel 8 (// Ant. 7.96-110) and 10 (// 7.117-129).

38 Compare 12:7b $\beta$ : "I [God] delivered you out of the hand of Saul". The reference is to the account of Saul's murderous, though unavailing, pursuit of David as described in 1 Samuel 18-26.

39 This allusion to David's various "legitimate" wives (see 1 Sam 25:42-43; 2 Sam 3:1-5) is Josephus compression of/replacement for the list of additional divine benefits given in 2 Samuel 12:8: "and I gave you your master's house, and your master's wives into your bosom, and gave you the house of Israel and Judah; and if this were too little, I would add to you as much besides". In this formulation it is especially the reference to God's awarding David the wives of Saul ("your master") which poses difficulties, given that this happening is not recorded elsewhere and, in fact, the Bible mentions only one actual wife of Saul, i.e. "Ahinoam" (see 1 Sam 14:50). Josephus disposes of the difficulty by turning the reference into an allusion to another, biblically-attested happening, namely, David's contacting a variety of marriages - with women other than the wives of Saul.

40 Generally, commentators see the LXX L reading as the original one, while that of MT and LXX B would be an attempt to attenuate the charge against David. 
took another's wife in marriage and caused his death by giving him to the enemy".

The conclusion to Nathan's judgment speech consists of the punishments announced by him for the king in 12:10-12. This segment commences with the hyperbolic announcement about the sword "never departing" from David's house (12:10a), coupled with a reiteration (12:10b) of the charges about David's having despised the Lord and married Uriah's wife from 12:9. Josephus' own rendering at the opening of $7.152 \mathrm{a}$ reduces this sequence to a general lead-in to the subsequent, more precise punishments that David will

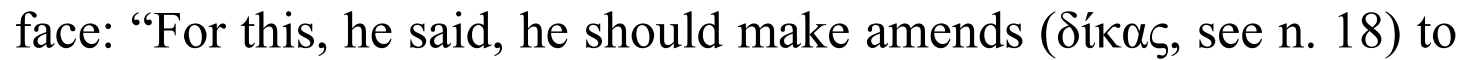
God...". In 12:11-12 Nathan announces a much more specific punishment for David, i.e. the public violation of his concubines by a "neighbour" of his to whom God will give the women in retaliation for David's own secret sexual crime. The historian takes care (7.152a) to adjust the language of this prediction to the actual course of future events, thereby accentuating Nathan's predictive powers: "... and his wives should be violated by one of his sons, and he too should be plotted against by this same son; and for this sin $(\square \mu \alpha ́ \tau \eta \mu \alpha)$, which he had committed secretly, he should suffer the

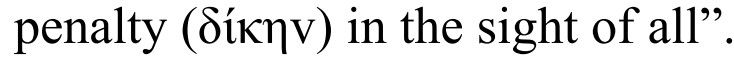

41 Josephus' mention of David's adultery prior to his murder of Uriah rather than the reverse as in $12: 9 \mathrm{a} \beta \mathrm{b}$ - has in view the sequence of events as related in 2 Samuel 11 (// Ant. 7.129b-146).

42 In 12:11 the future violator is designated more vaguely as "your neighbour". Josephus specification concerning his identity is based on 2 Samuel 16:21-22 (// Ant. 7.213).

43 This further announcement concerning Absalom's offenses against his father has no parallel in Nathan's word of 12:11. It is inspired by the fact that Absalom's violation of David's concubines occurred in the context of his revolt against the king (see 2 Sam 15:7-12), a happening which the Josephan Nathan predicts as well.

44 Compare 2 Samuel 12:11b-12: "and he [the neighbor] shall lie with your wives in the sight of the sun. For you did it secretly, but I will do this thing before all Israel, and before the sun". Josephus' version eliminates the Bible's double (anthropomorphic) reference to the "sight" of the "sun", as well as its making God himself the direct subject ("I shall do this thing") of the unsavory proceedings. 
At this juncture in the biblical account, David responds (12:13a) to Nathan with a confession of sin, to which the latter replies with a double announcement: David himself will not die (v. $13 \mathrm{~b}$ ), but the son of his sin will do so (v. 14). Re-arranging this sequence, Josephus (7.152c) makes Nathan's word about the infant's fate precede David's confession as the climax to his predictions concerning the punishments awaiting the king: "Furthermore the son whom she would bear him ( $\gamma \varepsilon \gamma \varepsilon v \eta \mu \varepsilon$ vov $\sigma 0 \imath)$ would die soon after birth".

The biblical David confesses his misdeed with the laconic words "I have sinned against the Lord" of v. 13a. Josephus' presentation (7.153a) of this key narrative moment is considerably more elaborate: "At these words the king was greatly dismayed and

45 In thus re-ordering the biblical sequence, Josephus obviates the anticlimatic (and off-putting) movement of Nathan's words in which a seemingly all-encompassing assurance of divine pardon and guarantee of life for David (v. $13 \mathrm{~b}$ ) is followed by a harsh qualification, i.e. the certain death of his son (v. 14).

46 Marcus's rendition of the above Greek appears problematic in a double respect: he translates the perfect participle as referring to the future ("would be born"), whereas according to 7.146 (// 2 Sam 11:27b $\alpha$ ) Bathsheba has already borne David their son. In addition, Marcus's rendition neglects the shift from the indirect discourse used for Nathan's words concerning David in what precedes to direct address to him with the preposition ool ("to you") for the prophet's climactic punishment announcement.

47 Compare Nathan's announcement in 12:14: "Nevertheless, because by this deed you have utterly despised the Lord [thus RSV, following the reading of the LXX MS c=376; MT LXX BL all have the euphemistic enemies of the Lord, while 4QSam ${ }^{\mathrm{a}}$ has a different euphemism, i.e. the word of the Lord], the child that is born to you shall die". Josephus' rendition omits the renewal of the charges about David's contempt for the Lord already voiced in 12:9a $\alpha$ [// 7.151], $10 \mathrm{~b}$.

48 Compare his expansion of Nathan's similarly laconic affirmation ("you are the man") of $12: 7 \mathrm{a} \alpha$ in $7.150 \mathrm{~b}$. Elsewhere as well, Jewish tradition accentuates David's penitence. Thus, Apocalypse of Sedrach 14.4 avers that "David (was saved) because of tears" (compare Josephus' interjected mention of these in 7.153), while in S. Eli. Rab. 2 (p. 7) David pleads that God use the fact of his full repentance and the resultant divine forgiveness as an encouragement to sinners. See also Sanh. 107a where the words of Ps 11:1b ("how can you say to me 'Flee like a bird to the mountains'..."?) are taken to refer to David's entreaty that God forgive him lest people say that "your 
troubled, and with tears of grief ( $\mu \varepsilon \tau \square \delta \alpha \kappa \rho v ́ \omega \mathrm{v} \kappa \alpha \hat{A} \lambda \hat{\pi} \pi \eta \varsigma$ [see $\mid \lambda v ́ \pi \eta \sigma \varepsilon v$, see 7.150 ; cf. n. 28]) admitted his impiety $(\bullet \sigma \varepsilon \beta-\sigma \alpha \imath)-$ for he was, as all agreed, a god-fearing $(\theta \varepsilon 0 \sigma \varepsilon \beta \eta \dot{\zeta})$ and never sinned ( $\square \mu \alpha \rho \tau$ äv, see $\square \mu \alpha \alpha \rho \tau \eta \mu \alpha, 7.152$; cf. also David's confession 'I have sinned' [LXX $\stackrel{\circ}{\mu \alpha \rho \tau \eta ் \kappa}$ ] in 12:13a) except in the matter of Uriah’s wife -...”.

Having thus elaborated on David's confession (12:13a), Josephus (7.153b) likewise expatiates on the (first part of) the divine response to this as mediated by Nathan in 12:13b: “... whereupon God took pity on him and was reconciled (î $\kappa \tau \varepsilon \iota \rho \varepsilon V . . . ~ \kappa \alpha \hat{A}$ $\delta i \alpha \lambda \lambda \alpha \dot{\alpha} \tau \varepsilon \tau \alpha)$ to him. And he promised to preserve both his life and

mountain [i.e. the king] has been put to flight by a bird [the reference here is to an earlier portion of Sanh. 107a which records a tradition that Satan appeared to David in the form of a bird, against which David shot an arrow that pierced the screen behind which Bathsheba was washing her hair]". Finally, b. 'Abod. Zar. 4b-5a avers that David's sin and repentance was something actually predestined by God in order that sinners, looking to his experience, might find confidence in the efficacy of their own repentance.

49 Josephus interjects this mention of David's emotional state in the face of Nathan's judgment speech as a preface to the king's verbal confession.

50 This hendiadys echoes the reference to Bathsheba's "grieving and

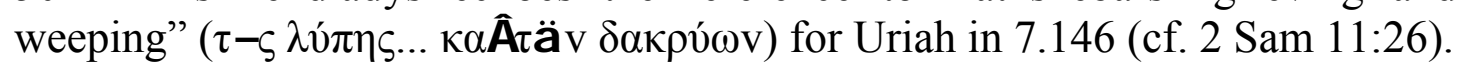

51 This term of Josephus' confession picks up on Nathan's charge (7.151) that God had been "impiously treated" $(\bullet \sigma \varepsilon \beta \eta \theta \varepsilon ́ v \tau o \varsigma)$ by the king. David now makes that accusation a self-accusation.

52 This is the same term Josephus uses to qualify David in his preface to the story of the king's fall in 7.130: "Now David, although he was by nature a righteous and god-fearing $(\theta \varepsilon 0 \sigma \varepsilon \beta \varepsilon \tilde{A}$ man...". In both instances, the term reminds readers of just how "out of character" David's misdeed was for him. (One finds a similar emphasis in b. 'Abod. Zar. 4b where it is affirmed that David was "not the sort of man" to commit his sin with Bathsheba, just as the Israelite were not the sort of people to worship the Golden Calf.)

53 The above editorial comment serves to explain the alacrity of David's confession - this is how a "god-fearing" man like David would be expected to behave in such circumstances. The wording of the comment seems inspired by 1 Kings 15:5: “... David did what was right in the eyes of the Lord and did not turn aside from anything that he commanded him all the days of his life, except in the matter of Uriah the Hittite".

54 This verbal combination occurs only here in Josephus. Its reference to God's being "reconciled" ( $\delta 1 \alpha \lambda \lambda \alpha$ á $\tau \varepsilon \tau \alpha l)$ to David is a negative echo of Ant. 
his kingdom, for, He said, now that he repented ( $\left.\mu \varepsilon \tau \alpha v o \tau_{\tau \imath}\right)$ of his

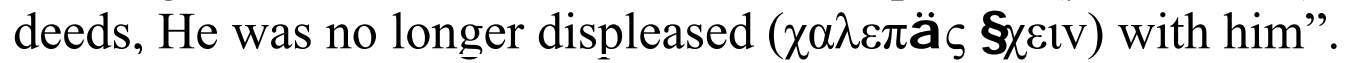

The entire exchange between king and prophet (12:1-14// 7.148-153) ends with the latter's return home in 12:15a. Josephus' rendition $(7.153 \mathrm{c})$ of this concluding development reads: "Then Nathan, after prophesying ( returned to his home".

6.151 where Samuel perceives that God is "not to be reconciled" ( $\delta 1 \alpha \lambda \lambda \alpha \tau \tau o ́ \mu \varepsilon v o v)$ with Saul.

55 This editorial notice might be seen as Josephus' transposition into narrative of Nathan's initial word to David in 12:13: "The Lord has put away your sin". Whereas in both the Bible and Josephus David's repentance evokes an immediate (and full) divine reconciliation with the king personally, in b. Sabb. 30a one hears that God responded to David's appeal that he be given a "token" of the Deity's forgiveness with the announcement that this will be given only in the lifetime of his son Solomon - as in fact happens when, at the dedication of the Temple, Solomon pronounces the words of 2 Chronicles 6:42 ("O Lord God, do not turn away the face of thy anointed one! Remember thy steadfast love for David thy servant") and David's enemies are confounded and all Israel realizes that David has indeed been forgiven. Note too that b. Yoma $22 \mathrm{~b}$, going beyond the Bible (and Josephus), avers that David personally had to bear a series of afflictions for his sin with Bathsheba: he was smitten with leprosy for six months, during which time the Sanhedrin withdrew from him and the Shekinah abandoned him.

56 In 2 Samuel 12:13b Nathan's announcement is simply that David's life will be spared. Josephus extends the assurance to encompass David's kingship as well, thereby answering his (and the reader's) question on the matter of David's future status.

57 On "repentance" in Josephus and his terminology for this, see A Schlatter, 1932, 146-147; E K Dietrich, 1936, 305-316.

58 This formula represents the reversal of the reference to God's "being angry" ( $\left.\delta u^{\prime} I I \rho \rho-\zeta \S \chi \omega v\right)$ at David with which Josephus begins his version of 2 Samuel 12 in 7.147.

59 This appended motivation - see its opening particle "for" - elucidates the reason why God has changed his earlier, "wrathful" stance towards David (cf. previous note). It likewise reinforces Josephus' earlier editorial notice about God's "taking pity on and being reconciled with" the king.

60 This verbal form constitutes an inclusio with the designation of Nathan

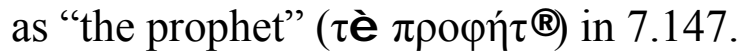




\section{DEATH \& BIRTH}

The extended segment 2 Samuel 12:15b-25 (// 7.154-158) narrates the immediate sequels to the king-prophet exchange, Nathan's announcement (12:14// 7.152b) about the fate of David's new-born son in particular. A new divine initiative sets matters in motion at this point: The Lord (MT LXX B; God, LXX L "strikes" the infant and it "becomes sick" (12:15b). In relating this development, Josephus (7.154a) follows the Bible in attributing the child's plight directly and immediately to God: "Now upon the child whom Uriah's wife bore to David the Deity ( $\tau \hat{\imath} \theta \varepsilon \tilde{A} v)$ caused a grave illness to fall...".

David responds to the God-sent illness of his child with an array of supplicatory gestures (12:16), likewise rebuffing his courtiers' attempts at intervention (12:17). The historian's version (7.154b) both re-arranges and amplifies this source sequence:

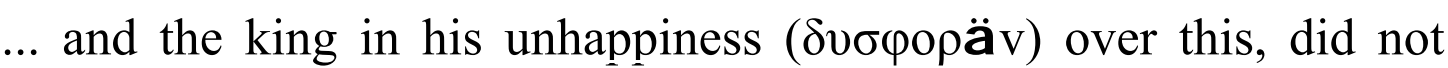
partake of food for seven days, although his servants tried to force him do so. Instead he put on a black garment and throwing

61 Josephus reproduces this ironic-sounding designation for Bathsheba from 12:15b - at this point she is, after all, David's own wife, her union with Uriah having ceased with the latter's death.

62 On Josephus' frequent substitution of this Hellenistic designation for biblical references to "God" or "the Lord", see Shutt (1980:171-189).

63 This participial form echoes the mention of David's being "greatly

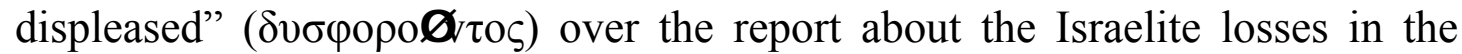
siege of Rabbah sent him by Joab in Ant. 7.142. Now David has something else, of a much more personal nature, to be "displeased" over.

64 Josephus inserts this allusion to the king's emotional state that prompts his turning to God (12:16).

65 Cf. 12:16aß: "and David fasted". Josephus' specification concerning the duration of his fast has in view the indication of 12:18 that the child died "on the seventh day".

66 This notice is Josephus' compressed version of 12:17: "And the elders of his house stood beside him [MT LXX B; LXX L: approached him] to raise him from the ground; but he would not, nor did he eat food with them".

67 This initiative by David lacks a biblical counterpart. For references to the wearing of black garments by (accused) suppliants in Rabbinic tradition (b. 
himself upon sackcloth, lay on the ground, beseeching God to

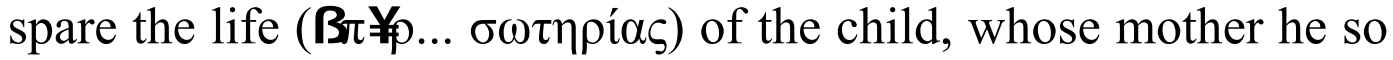

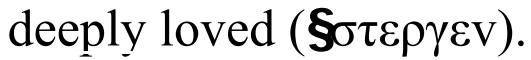

David's pleas notwithstanding, the child dies "on the seventh day" $(12: 18 \mathrm{a} \alpha)$, an event which the servants, given the intensity of the king's previous supplication, are hesitant to report to him (12:18aßb). Josephus (7.155) turns the servants' conversation $(12: 18 b)$ on the matter into an extended editorial notice on their state of mind vis-à-vis what they have witnessed of the king's earlier distress:

But on the seventh day the child died, and the servants dared (1 $\tau$ ' $\lambda \mu \omega \mathrm{v}$; see the double use of this verb in 7.150) not inform the king, for they feared that when he learned of it he might even more completely refuse food and other necessary care, in his desolation ( $\pi \circ \theta \varepsilon i v o \varnothing)$ at the death of his son, seeing that even during the child's

Mo'ed Qat. 17a) and elsewhere in the Josephan corpus (BJ 1.506; Ant. 14.172), see Nodet (2001: 164-164).

68 Josephus' reference to David's use of "sackcloth" on this occasion has a parallel in the reading of LXX L (and 4QSam") 12:16b: "and he lay in sackcloth on the ground".

69 This indication concerning the place where David positions himself corresponds to the notice of 12:16b "he lay all night upon the ground (MT LXX B; LXX L: he lay in sackcloth upon the ground; see previous note). Like LXX L, Josephus lacks an equivalent to the mention of David's "spending the night" on the ground". He likewise has no counterpart to all these witnesses' (odd) preceding reference to the king's "going in" which leaves unspecified where it was David entered.

70 Compare 12:16aa: "David therefore besought God for the child". Josephus spells out what it is the king asks from God for the child.

71 This motivation for David's supplication lacks an equivalent in the Bible (which nowhere mentions such an emotional bond David and Bathsheba).

72 Compare the servants' concluding statement in 12:18b: "He [David] may do himself some harm".

73 This is the conjecture of Niese which Marcus follows. Nodet reads $\pi \varepsilon ́ v \theta \varepsilon 1$ with the codices SP and the Latin translation.

74 This inserted allusion to the servants' surmise as to how David will respond emotionally to news of his son's death, echoes Josephus' - likewise inserted - reference to David's "unhappiness" over the child's malady in 7.154 
illness, he had in his grief ( $\left.₫ \pi \hat{\imath} \tau-\zeta \lambda v^{\prime} \pi \eta \varsigma\right)$, he had so greatly afflicted (| Кókov) himself.

In 2 Samuel 12:19 the focus shifts back to David who, seeing the servants "whispering together", infers that the child is dead, a supposition which the servants confirm when questioned by him. The Josephan equivalent (7.156a) to this notice elaborates on the servants' behavior as observed by David: "The king, however, perceived that they were disturbed and were acting in such a manner as is usual with those who wish to conceal something, and so he realized that the child had died. Then he called to him one of the servants and, when he had learned the truth...".

2 Samuel 12:20 describes the various, surprisingly "positive" measures taken by David in response to the servants" report. Josephus (7.156b-157a) retains most elements of the biblical catalogue of David's initiatives, even while modifying this in several details: "... he arose, bathed, put on a white garment and went to the tent of God; and when he ordered a meal to be set before him...".

and will itself be picked up in the mention of the "grief" that prompted David's supplication for the infant in the continuation of 7.155.

See n. 28 and previous note.

75 Compare the servants' words to one another in 12:18ba: "Behold, while the child was yet alive, we spoke to him, and he did not listen to us. How then can we say to him the child is dead"?

In 12:19b $\alpha$ David addresses the servants as a group.

76 This transitional remark replaces the brief dialogue recorded between David and the servants recorded in 12:19b: "(and David said to his servants), 'Is the child dead?' They said, 'He is dead'".

77 These first two actions of the king are the same with which the catalogue of 12:19 begins. Josephus omits the third royal action cited there, i.e. David's "anointing" himself.

782 Samuel 12:19 speaks more generally of the king's "changing his clothes". David's switch to white here, reverses his donning "black garments" in 7.154. On white as the color of festivity and joy, see Qohelet 9:8 ("let your garments be always white; let not oil be lacking on your head"). Cf. also the Rabbinic prescriptions concerning the wearing of while garments on various festive occasions cited in Rappaport (1930:53, 131).

79 Josephus rewords the reference in 12:19 to David's "going to the house of the Lord" which appears to be an anachronistic reference to the Temple 
Mystified by David's actions (12:20) the servants immediately voice their puzzlement to the king in 12:21. The historian prefaces, in the continuation of 7.157a, their address to David with a notice on the inner effect of the king's behavior on them: “... he caused great astonishment at his strange conduct among his relatives and servants, because he none of these things during the child's illness but was suddenly doing them now that he was dead". Thereafter, he has them (7.157b) request permission to query the king prior to their actually doing this: "So, having first requested permission to inquire, they asked him to tell them the reasons for these acts".

David responds at length to the servants' inquiry of 12:21 in 12:22-23: his supplicatory gestures had some prospect of efficacy while the child still lived (v. 22), but become pointless once it died (v. 23). The Josephan David (7.158a) prefaces his explanation with a derogatory remark about the servants' acumen and concludes the explanation with mention of the retainers' response to the royal words:

which was not yet in existence in David's time. On David's erection of a "tent" for the ark in Jerusalem, see Ant. 7.86 (// 1 Chronicles 15:1; 16:1). Josephus has no equivalent to the appended mention of David's "worshiping" in the house of the Lord of 12:19.

80 Josephus compresses the last three actions of David subsequent to his child's death as cited in 12:19: "he then went to his own house; and when he asked, they set food before him, and he ate".

81 This group is not mentioned in 2 Samuel 12 where the exchange is simply between David and his servants.

82 For the conclusion of the above notice Josephus draws on, while also reversing the order of, the servants' words to David as cited in 12:20: "you fasted and wept [LXX BL and VL add: and kept vigil] for the child while it was alive, but when the child arose and ate foot [LXX BL add: and drank]".

83 Concern for the observance of proper protocol is a recurring feature of Josephus' retelling of biblical incidents involving interactions between kings and subjects and where the latter often appear "forward" in their approach to the former. For a case in point, see Begg (1993:222).

84 Having anticipated the content of the servants' words to David of 12:20 in his notice on their "astonishment" at the king's behavior (see n. 85), Josephus confines himself to this brief allusion to what they actually said to David. 
Thereupon he called them dullards $(\bullet \mu \alpha \theta \varepsilon \tilde{\mathrm{A}})$, and explained that while the child was still alive, he had hoped for its recovery ( $\sigma \omega \tau \eta \rho i ́ \alpha$; see 7.154), with the thought of rendering God gracious $(\varepsilon \hat{U} \mu \varepsilon v \rightarrow)$ to him by such means; but now that it was dead, he no longer had any need of vain grief ( $\lambda \dot{\pi} \pi \eta \varsigma$ [see n. 28] $\mu \alpha \tau \alpha i \alpha \varsigma)$. At these words they praised the king's wisdom and

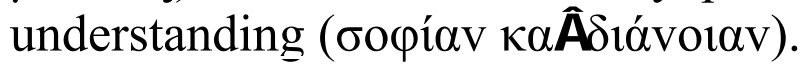

The biblical story takes a new, positive turn in 2 Samuel 12:24-25 where David and Bathsheba have a second son who receives a double name, first "Solomon", and then "Jedidiah". Josephus' version (7.158) offers a compressed version of these developments: "Then David lay with his wife Beethsab and she conceived and bore

85 This interjected comment by David serves to highlight the king's clear superiority in the relationship between him and the servants; the latter had already taken care to ask permission to speak before querying the king (see 7.157b and n. 86); now they must submit to verbal abuse by him.

86 Schlatter (1932:30) points out that the adjective $\varepsilon$ Ûuвvís is the term most frequently used by Josephus to refer to God's benevolent stance towards humans.

87 Compare David's explanation of his earlier behavior in 12:22: "While the child was still alive, I fasted and wept; for I said 'Who knows whether the Lord will be gracious to me (LXX $\mid \lambda \varepsilon \eta ́ \sigma \varepsilon 1 \mu \varepsilon)$, that the child may live"”?

This expression occurs only here in Josephus.

88 Josephus shortens David's explanation of his more recent behavior as cited in 12:23: "But now he is dead, why should I fast? Can I bring him back again [LXX L lacks again]? I shall go to him, but he will not return to me". In particular, he leaves aside the king's reflections on the irrecoverability of the dead and the certainty of his own death.

89 This collocation occurs (in reverse order) also in Ant. 12.110.

90 Josephus' appending of this notice on the servants' response to David's words of 12:22-23 serves to underscore, once again (see nn. 85, 87), the asymmetry of their relationship: the king called them "dullards", while they acclaim his mental capacities. The acclamation was perhaps inspired by the audience's response to the wise judgment of Solomon in the case of the two harlot mothers in 1 Kgs 3:28 (in Josephus' version of this response in Ant. 8.34, both terms used to denote David's acumen [see above] recur).

This item has a counterpart in LXX BL 12:24, but not in MT. 
a son, whom he named Solomon at the bidding ( $\kappa \varepsilon \lambda \varepsilon v ́ \sigma \alpha v \tau o \zeta)$ of the prophet Nathan".

\section{RABBAH CONQUERED}

2 Samuel 12 concludes, in vv. 26-31, by relating the outcome of the siege of Rabbah that was initiated by Joab already in 2 Samuel 11:1, but which has not been mentioned since 11:25. The problems posed by the concluding segment of chap. 12 begin with its first two verses where there is successive mention of Joab's capture of "the royal city" (12:26) and "the city of the waters" (12:27) - are these two different names for the same entity or not? The problem does not arise in the presentation of Josephus, who (7.159) has no equivalent to the former phrase, but who, instead, develops a whole midrashic elaboration around Joab's report to David concerning his capture of the Ammonite "city of waters" in 12:27b $\beta$ :

Now Joab in besieging the Ammonites was inflicting great damage (| Kókov; see 7.155) on them by cutting off their water

91 In having David name the son, Josephus aligns himself with the MT ketiv, whereas the qere (and Tg.) attribute the naming to Bathsheba (the LXX

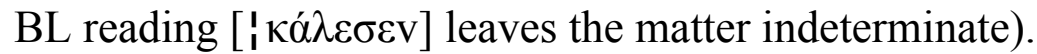

92 This concluding phrase takes the place of the complex of notices in 12:24b $\beta-25$ : "And the Lord loved him (Solomon), and sent a message by Nathan the prophet; so he called his name Jedidiah, because of the Lord (thus MT LXX B; by [lv] the word of the Lord; VL: quod est interpretatum in verbo Domini; Vulg.: [et vocavit nomen eius Amabilis Domino] eo quod diligeret eum Dominus). Josephus thus omits Solomon's other name (as well as the related reference to the Lord's "loving" him), likely because this name is nowhere used for Solomon elsewhere in the Bible. As a result, in Josephus' presentation, Nathan's intervention causes David to name his child not "Jedidiah", but rather "Solomon".

93 On the question, see the commentaries. In the Tg. (as well as two Hebrew MSS and the Peshitta) the designation "royal city" appears in both verses. In the Chronicler's version of Rabbah's capture in 1 Chronicles 20:1-3 one finds (v. 1b $\beta$ ) only a general allusion to Joab's "smiting" and "overthrowing” Rabbah.

94 Josephus reduces to this single allusion the double biblical mention of Joab's siege of Rabbah, first in the editorial notice of 12:26a and then in the general's report to David in 12:27ba.

95 Compare 12:27b $\beta$ where Joab reports to David his capture of "the city of waters". 
and other supplies, so that they were in a very pitiable condition for lack of food and drink, for they were dependent on a small well and this had to be carefully controlled in order that the spring might not fail them altogether because of too frequent use. (7.160) Accordingly, he [Joab] wrote to the king, informing him of this...

Joab's message to David continues in 12:28 with the general urging the king to personally undertake the capture of Rabbah, lest if he (Joab) do this, the city be called by his name. Having expatiated on the content of 12:26-27, Josephus compresses in his parallel to this portion of Joab's communication: "... and inviting him to come to capture of the victory ascribed to himself". On the other hand, he does supply (7.160b) a reaction by David to Joab's message about which the Bible itself says nothing: "Upon receiving Joab's letter, the king commended his loyalty and faithfulness (\&Û́toías $\kappa \alpha \hat{A}$

96 With his reference to the "small well" on which the Ammonites depended once Joab had cut off their water supply, Josephus suggests an explanation as to how the city could have continued to hold out - as is presumed in the continuation of the biblical account - even after Joab had captured its (primary) "water supply": the inhabitants still had this well to draw on.

97 In 2 Samuel 12:27a Joab sends "messengers" to the king who speak to David. In portraying as Joab communicating with David in writing, Josephus has him employ the same medium David himself used when imparting instructions to Joab about the elimination of Uriah in 2 Samuel 11:14-15 (// Ant. 7.135).

98 Having anticipated the content of Joab's message about his assault on Rabbah and capture of the "city of waters" from 12:27b in the notices of 7.159, Josephus confines himself here to this summary allusion to the content of Joab's report about his military successes. Compare his similar handling of the servants' querying of David (12:21) in 7.157; see n. 87.

99 Compare the more circumstantial formulation of Joab's exhortation to David in 12:28: "Now, then, gather the rest of the people together, and encamp against the city, and take it, lest I take the city, and it be called by my name". Josephus' version gives a positive turn to the motivation Joab adduces in requesting David's presence for the city's fall, just as he elucidates the meaning of the general's reference to the "calling" of the city's "by the name of" the one who captures it. 
$\pi i \sigma \tau \varepsilon \omega \varsigma)$ ). To the notice on David's acting in according with Joab's suggestions (12:29), he appends (7.160c) a remark that underscores David's concern - as the omni-competent general he is - to keep his troops happy: "... then he took along the force that was with him and came for the sacking of Rabatha, which he took by force, and allowed his soldiers to plunder".

The problem-filled vv. $30-31$ of 2 Samuel 12 (themselves partially paralleled in $1 \mathrm{Chr}$ 20:2-3) relate a series of measures taken by David subsequent to Rabbah's fall. The first of these measures involves a "crown" which David removes from the head of its previous wearer. Who, though was that earlier crown-wearer? According to MT, 4QSam ${ }^{\mathrm{a}}$, LXX L, Tg., and Vulg. 2 Samuel 12:30a $\alpha$ (as also MT LXX L and Tg. $1 \mathrm{Chr} 20: 2 \mathrm{a} \alpha$ ), it was an anonymous figure designated simply as "their (the Ammonites) king", while in various other witnesses to both accounts this

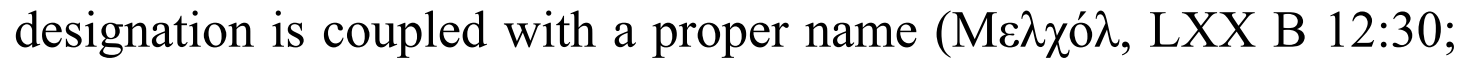
Mo $\chi$ ó $\lambda$, LXX B 20:2; compare Vulg. 20:2 where Melchom stands alone without any further identification), which itself is generally taken as a variant form of the name of the Ammonite chief god, Milchom (see $1 \mathrm{Kgs} \mathrm{11:5).} \mathrm{In} \mathrm{this} \mathrm{instance,} \mathrm{Josephus} \mathrm{(7.161a)}$ clearly aligns himself with the reading of the first set of witnesses just cited: "He himself took the crown of the Ammanite king". According to virtually all witnesses for the text of 2 Samuel 12:30 and 1 Chronicles 20:2, the weight of the crown taken by David was

100 This collocation occurs also in BJ 7.365; Ant. 6.276; 14.162; 17.32,139; Vita 84 and in reverse order in Ant. 7.212; 11.217; 17.194; cf. 16.21; 17.31.

101 In the sequence of 12:28-29, David's taking of his force with him to Rabbah (v. 29) is done in accordance with Joab's previous suggestion (v. 28). Josephus, who lacks an equivalent to the former item (see n. 105), has the king act on his own initiative in the matter.

102 David's "permission" here is reminiscent of the practice of Roman generals who, particularly where a siege had been long and arduous and/or the inhabitants especially odious - both conditions certainly met by Rabbah and its population - rewarded their troops in this way; see, e.g., Caesar, Bell. Gall. 7.89 .

103 On 2 Samuel 12:30-31, see the influential article of O'Ceallaigh (1962:179-189). 
"a talent of gold", a datum which Josephus reproduces as well: “... which weighted a talent of gold". 2 Samuel 12:30 and 1 Chronicles 20:2 go on to mention another object(s) of value. The witnesses to the two verses differ, however, among themselves as to the number of objects involved and how it (they) relate to the just-cited crown: MT and LXX BL 12:30 (and LXX B 20:2 simply juxtapose the two items (a crown and a precious stone), while MT LXX L, Tg. 20:2 and Tg. 12:30 specify that the stone was "in it" (i.e. the crown), while Vulg. 12:30 and 20:2 speak of "precious gems" (gemmas pretiossissimas). The historian's rendition corresponds to the reading of MT 20:2, etc., while also appending a specification concerning the identity of the stone: "and had at its center a precious stone, a sardonyx". 2 Samuel 12:30a// 1 Chronicles 20:2a conclude by noting that "it [the stone?, the crown?] was [placed; the word is supplied in the RSV translation] on David's head", leaving it unclear whether this was a one-time happening or not. Josephus' rendering resolves the "chronological" question: "... and thereafter David always wore it ( $\alpha$ Û́óv) on his own head".

104 Compare, however, Tg. 1 Chronicles 20:2 where the word "talent" of MT is replaced with a Latin borrowing, i.e. centanarium and it is specified that this was of "pure gold".

105 Tg. 1 Chronicles 20:2 adds that the stone had a value equivalent to that of the crown itself, i.e. "a centenarium of pure gold".

106 This question arises for those witnesses (MT 12:30, etc.) which do not spell out the relationship between the "crown" and the "stone". In the case of the witnesses (MT 20:2, etc.) that do explicitly represent the latter as a component of the former, the "it" can only be the crown that itself contains the precious stone.

107 As in MT 1 Chronicles 20:2, etc. (see previous note) the referent of Josephus' pronoun here can only be the crown, since in what precedes the historian has specified that the precious stone was itself situated "in the centre" of this.

108 In thus speaking explicitly of David's "wearing" the crown and by adding that he did this "always", Josephus exacerbates a difficulty that the biblical presentation itself already suggests, i.e. how could the king sustain the weight of so heavy a crown, i.e. one weighing "a talent of gold" (= ca. 66 pounds, $30 \mathrm{kgs}$.; see Anderson (1989). Jewish tradition (see b. Abod. Zar. 44a) proposes various solutions to the difficulty: David did not actually wear the crown, but was fit to do so; the stone spoken of in 12:30// 2 Chronicles 20:2 functioned as a magnet that held the crown suspended over - rather than on the 
The mention of two precious objects appropriated by David in $12: 30 \mathrm{a} / / 20: 2 \mathrm{a}$ is generalized in $12: 30 \mathrm{~b} / / 20: 2 \mathrm{~b}$ with mention of the vast "spoil" the king brings out of captured Rabbah. Josephus (7.161b) accentuates the value of this additional plunder: "He also found much other splendid and valuable $\left(\lambda \alpha \mu \pi \rho \square \kappa \alpha \hat{A} \pi \mathrm{\alpha} \lambda v^{\tau} \tau \mu \alpha\right)$ in the city".

As with those cited in 2 Samuel 12:30a// 1 Chronicles 20:2a, the measures attributed to David $12: 31 \mathrm{a} / / 20: 3 \mathrm{a}$ pose numerous interpretative difficulties, given the marked differences between the two verses (and among their various witnesses). It is not necessary for us to enter here into all the details of these difficulties and differences here, given that many of them are not relevant to Josephus' own presentation of the king's initiatives at this point, which clearly itself aligns with one rather than the other of the biblical portrayals of these. It suffices to note that whereas $12: 31 \mathrm{a}$ seems to represents David imposing forced labor, involving an array of "tools" on the inhabitants of Rabbah, 20:3a (and VL and Vulg. 12:30a; see n. 116) envisages him inflicting a still more severe punishment on them, i.e. "sawing" them with assorted iron implements. The Josephan rendering (7.161c), for its part, unequivocally reflects the latter understanding of David's initiative

king's head; the biblical verses refer to the value of the precious stone rather than to weight of the crown itself. In any case, the Tg. on 2 Chronicles 23:11 (the crowning of the boy Joash) identifies the crown used on that occasion with the one taken by David from the Ammonite king. The Tg.'s reading goes on to aver that the crown contained a magnetic jewel, placed there by David under the inspiration of God's spirit, on which was inscribed the divine name. Moreover, the crown's character was such that it would only fit the head of a descendant of David - as happens with Joash; see McIvor (1994).

This word is hapax in Josephus.

109 See RSV's rendering of (MT) 12:30a: "And he [David] brought forth the people who were in it, and set them to labor [LXX L: tortured; VL and Vulg.: sawed= MT 20:3] with saws and iron picks and iron axes, and made them toil at [this is a conjecture for MT's pass through] the brickkilns [LXX reads a proper place name here, i.e. in Madebba; compare Tg.: dragged them through the streets]". 
(even while markedly generalizing this): "As for the inhabitants, he

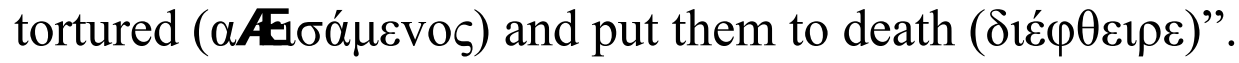

2 Samuel 12:31ba// 1 Chronicles 20:3b $\alpha$ represent David extending his punitive measures against Rabbath to all the Ammonite cites. The Josephan David (7.161d) does the same: "And the other Ammanite cities, which he took by force (Qãv... к $\alpha \tau \square$

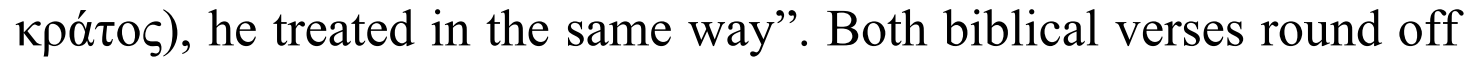
their account of David's initiatives in Ammon by noting (12:31b $\beta / /$ $20: 3 \mathrm{~b} \beta$ ) the return of king and people to Jerusalem. Josephus' parallel notice (7.162a) serves rather to introduce the following episode of his presentation (7.162-180) i.e. the rape of Tamar by Amnon which he draws from 2 Samuel 13.

\section{CONCLUSION}

At the conclusion of this essay, I return to the overarching questions concerning Ant. 7.147-161 which I formulated at its opening in order to sum up on my findings concerning these. My first question above involved the text-critical affinities of Josephus' relecture of 2 Samuel 12. The foregoing comparison did yield several data of relevance for this question. Thus, e.g., Nathan's asking David for his opinion about the case he is about to present in 7.148 has a

110 Greek - v $\delta \rho \alpha \varsigma$, literally: "males" (Nodet, ad loc. "homes"). Josephus' use of this term may be intended to attenuate the harshness of David's measure as related in $20: 3$ by indicating that this was perpetrated only the "men" of Rabbah - not also the women and children.

111 This participial form might reflect the LXX L reading in 12:31 and the

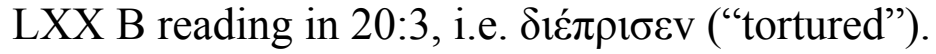

112 This general term takes the place of the more specific (and shocking) "he sawed them" used of David's measures against the inhabitants in MT 20:3. In contrast to both 12:31 and 20:3, Josephus makes no mention of the various iron implements used by (or on) the Rabbahites. Like the Chronicler, he further has no equivalent to the notice about David's making the captives "toil at (or pass through [MT; see n. 116] the brickkilns" of 12:31aß.

113 This inserted phrase introduces explicit mention of the presupposition for David's treating the remaining Ammonite cities as he had Rabbah itself, i.e. his capture of the former. The phrase used for this royal initiative is the same employed in 7.160 in connection with David's storming of Rabbah. Thereby, Josephus accentuates the parallelism between the fate suffered by Ammon's capital and its other cities at David's hands.

114 On Josephus' version of the Tamar episode, see Begg (1996:465-500). 
counterpart in the LXX plus in 2 Samuel 12:1. Josephus agrees (7.150) with MT and some LXX L manuscripts of 12:7 as to the extent ("fourfold") of the restitution prescribed by David contra the "sevenfold" of LXX BL*. His reference to the king's use of "sackcloth" in 7.154 parallels a similar allusion found in LXX L (and 4QSam ${ }^{\mathrm{a}}$ ) 12:16, but absent from MT and LXX B. The explicit mention of Bathsheba's "conceiving" in 7.158 corresponds to the LXX BL plus in 12:25. In referring (7.161) to the previous wearer of the crown appropriated by David simply as "the Ammanite king" he goes together with the MT and LXX L reading in 12:30, in contrast to LXX B which gives that king a name ("Melchol"). It appears then that Josephus' text-critical affinities in 7.147-161 are primarily with a form of 2 Samuel 12 that stood closest to that represented by our LXX L manuscripts. On the hand, it should be recalled that Josephus does not invariably agree with the readings of LXX L where this differs from other witnesses to the Samuel text. In 7.158, e.g., he aligns himself with MT LXX B 12:24 in having David lie with Bethsheba, whereas in LXX L it is the latter who lies with the former. The text-critical question of 7.147-161 is further complicated by the fact that in his account of David's measures following the fall of Rabbah, the historian seems to follow the presentation of 1 Chronicles 20:2-3 in preference to that of 2 Samuel 12:30-31 on several points (the relation between the "precious stone" and the "crown"; the killing of the inhabitants rather than the imposition of forced labor upon them).

In my second opening question above I asked about the rewriting techniques applied by Josephus to the data of 2 Samuel 12 and the distinctiveness of his own version of events that results from their application. A first such technique that recurs throughout 7.147-161 is the historian's additions to/expansions of source items, these ranging from a word or two to entire sentences or paragraphs. Examples include: the inserted preface to Nathan's approach to David in 7.147b; God's making David king not only of the Israelites, but also of "many great nations around them" (7.151, compare 12:7); the interjected allusion to the revolt against David by the violator of his wives (7.152, compare 12:11), the amplifications surrounding David's repentance (7.153a, compare 12:13a) and God's acceptance of this (7.153b, compare 12:13b); the notices on David's donning a

115 For more on the Samuel text used by Josephus, see Ulrich (1989:81-96). 
black garment and his deep love for Bathsheba (7.154, compare $12: 16)$; the servants request to be allowed to query David (7.157, compare 12:21); the king's calling them "dullards" and their acclamation of his mental acumen (7.158, compare 12:22-23); the elaboration of the reference to the "city of waters" at Rabbah (12:27) in 7.159; David's commendation of Joab's fidelity in response to the latter's message to $\operatorname{him}$ (7.160, compare 12:27-28); the king's allowing his soldiers to plunder captured Rabbah (7.160, compare 12:29); the specification that the "precious stone" was a "sardonyx" (7.161, compare 12:30a// 20:2a), and David's storming of the other Ammonite cities (7.161, compare 12:31ba// 20:3ba). Conversely, however, Josephus also abbreviates or leaves aside entirely elements of 2 Samuel 12: several details concerning the lamb and the poor man's care for this (12:3, compare 7.148 in fine-149a), portions of Nathan's judgment speech (12:7aßb-12, compare 7.150b-152a); the motivation for the announced death of David's son (12:14b, compare 7.152); David's concluding reflection on the child's loss and his own eventual fate (12:23b, compare 7.158a); Solomon's other name ("Jedidiah") and the related mention of the Lord's "loving" him (12:24b $\beta-25$, compare 7.158c); Joab's capture of the "royal city" (12:26, compare 7.159); and various items having to do with David's treatment of the captured inhabitants of Rabbah (12:31a// 20:3a, compare 7.161).

Yet another re-writing technique employed by Josephus in 7.147-161 is re-arrangement of the biblical sequence. The most conspicuous instance of this device occurs in $7.152 \mathrm{~b}$ where Josephus anticipates Nathan's announcement about the death of David's son which in 2 Samuel 12 stands after (see v. 14) the king's confession of $\sin$ (see v. 13a). This same technique surfaces also elsewhere in Josephus' version, however. The order, e.g., of David's crimes as cited by Nathan in 12:9 is reversed in 7.151, just as is that of the two parts of David's sentence on the rich man (see 7.150, compare $12: 5 b-6)$.

Finally, Josephus also modifies the biblical presentation in still other ways throughout 7.147-161. On the stylistic-terminological level, he rewords source uses of "Lord" as a divine designation (see nn. 11, 63); reformulates "anointing language" (compare 7.151 and $12: 7$, see n. 36); does not reproduce the "oath and messenger formulas of $12: 5$ and 12:7 respectively (see nn. 29 and 34); on occasion recasts direct as indirect discourse (see n. 21); and works 
various Leitworte into his version, e.g., those of the $\delta 1 \kappa-$ and $\lambda v \pi-$ stems (see nn. 19,28). But modifications of a more contentual character are present as well. The Deity does not merely "send" Nathan (12:1), but "appears to him in a dream" and criticizes the king to him (7.147a); the rich man sends his retainers to take the lamb instead of doing this in person (7.149 and 12:4). David is "distressed" (7.150) rather than "angry" (12.5) at Nathan's story. God gives David "rightful and lawful" wives (7.151), not those of his master, i.e. Saul (so 12:8). The one who will violate David's wives is "one of his sons" (7.152) as opposed to "your neighbour" of $12: 12$. In 7.156 the king dons a "white garment" and goes to "the tent of God", while in 12:20, he "changes his clothes" and repairs to "the house of the Lord". David asks a single servant - rather than the servants en bloc (so 12:19) - about the fate of his child (7.156). The name David gives Bathsheba's second-born son on Nathan's instructions is "Solomon" (7.158), not "Jedidiah" (12:25). Finally, Joab communicates with David in writing (7.160), whereas his biblical counterpart employs messengers who speak to the king (12:27-28).

Given the historian's utilization of the above re-writing techniques, what now is distinctive about his version of 2 Samuel 12? Like the re-writing techniques themselves the distinctive features of 7.147-161 are many and manifold. A certain streamlining of the Vorlage and its repetitions/duplications occurs. E.g., Nathan's triple charge about David's having "despised" the Lord (see $12: 9,10,14 \mathrm{a})$ is reduced to a single one (7.151), just as are the double accusations concerning the king's killing of Uriah and taking of his wife in 12:9-10 (ibid.). At the same time, personages' psychology, i.e. the character traits and emotional states that underlie their words and actions receives considerably more explicit attention than in 2 Samuel 12 itself. Examples of this feature include the inserted references to Nathan's being a "man of tact and understanding" (7.147), to David's being "dismayed and greatly troubled" and his "tears of grief" in the face of Nathan's denunciation (7.153a), to the cessation of God's "displeasure" towards him (7.153b), to the king's "unhappiness" over his son's sickness and his "deep love" for the mother (7.154) that prompt his intercession for the infant, and to the servant's "astonishment" over David's behavior (7.157). Discrepancies between what one reads in 2 Samuel 12 and other biblical contexts are resolved in some fashion. Thus, the allusion to the 
Lord's having given David Saul's wives (12:7) is reworded (see 7.151), given the fact that this "donation" is not recorded elsewhere. Similarly, David's going to "the tent of God" (7.156) rather than the "house of the Lord" (12:20) is designed to eliminate the anachronism of the biblical formulation. In the same line, the problematic sequence in which various biblical items are presented in 2 Samuel 12 is rectified (the two parts of David's sentence on the rich man [12:5b-6, compare 150], the order in which Nathan mentions David's two crimes [compare 12:9 and 7.151] and the prophet's informing David of the certain death of his son after having announced divine pardon for the king himself [compare 12:13b-14 and 7.152-153). Roman sensibilities about contemporary Jewish "messianism" are deferred to via the reformulation of the reference to David's "anointing" (12:7) in 7.151 (see n. 36). A comparable concern with the "squeamishness quota" of Gentile readers may be operative in Josephus' attenuation of the gory details of David's slaughter of the Rabbahites cited in 1 Chronicles 20:3a (see nn. 118, 120). In connection with this last point, it is also noteworthy that in his retelling of 2 Samuel 12, Josephus does not limit himself to the data of that chapter, but makes (selective) use of the divergent particulars found in 1 Chronicles 20:2-3 as well.

The various characters featured in 2 Samuel 12 likewise undergo retouchings at Josephus' hands. God appears more "expansive" in his dealings with Nathan (compare 7.147 and 12:1), and more emotionally involved vis-à-vis David's repentance (compare $7.153 \mathrm{~b}$ and 12:13). Nathan is credited with a "tact and under-standing" and an insight into royal psychology that prompt him to adopt an indirect approach with the king (7.149), which, however, he leaves aside in order to reveal God's wrath "in plainest fashion" to David once David has pronounced judgment upon himself (see 7.151). The general Joab receives David's commendation for his "loyalty and faithfulness" (7.160). It is above, however, David himself to whom

116 On the other hand, Josephus actually "intensifies" the problem of David's wearing so heavy a crown as $12: 30$ a// 20:2a have him do with his specification (7.160) that he did this "always" (see n. 114).

117 On Josephus' overall presentation of Joab, see Feldman (1998a:203-14). As Feldman points out, Josephus' general tendency is to paint Joab in still darker colors than the Bible itself. Thus, the above commendation is one of the first instances where one sees the opposite tendency at work. 
Josephus applies the most "added touches" throughout 7.147-161. The king's repentance takes on a more emotional quality and it is emphasized just how "out of character" his misdeed was for him (7.153a, compare 12:13a). Likewise his emotional involvement in the face of his son's illness is accentuated, with this being attributed to David's "deep love" - of which the Bible itself never speaks - for the child's mother Bathsheba (compare 7.154 and 12:16-17). The king's position of superiority vis-à-vis his servants is also highlighted (compare 7.157-158 and 12:21-23): he speaks to them as his intellectual inferiors, while they acclaim his mental acumen. At the same time, the Josephan David also shows himself to be a king who knows how to effectively ingratiate himself with his soldiery: he praises the general Joab's devotion (7.160) and hands Rabbah over to plunder by his troops (ibid.). The impression left by these various retouchings of 2 Samuel 12's portrait of David by Josephus is thus a mixed one - although positive features clearly do predominate.

My third and final question concerned the relationship between Josephus' retelling of 2 Samuel 12 and the handling of the chapter's material elsewhere in (early) Jewish tradition. Here, we may confine ourselves to a few summary remarks on the matter. Like rabbinicmidrashic tradition overall, Josephus goes beyond the Bible in accentuating both David's repentance and God's positive response to this (see n. 49). In common with b. 'Abod. Zar. 4b, he insists that David' sin was indeed out of character for him (see n. 53). On the other hand, however, he does not align himself with the effort of some Rabbis to completely exonerate David of any wrongdoing with regard to Bathsheba and Uriah. Similarly, whereas b. 'Abod. Zar. $44 \mathrm{~b}$ attempts to resolve the problem of David's wearing so heavy a crown as spoken of 12:30a// 20:2a, Josephus even exacerbates the

118 On Josephus' overall portrait of David, which is marked, e.g., by a concern not to give undue play to the virtues and achievements of this ancestor of the Messiah lest Roman suspicions be aroused, see Feldman 1998b:537569).

119 On such efforts, see, e.g., b. Sabb. 56a where R. Samuel, speaking in R. Jonathan's name, avers, with reference to 1 Samuel 18:14 ("David had success in all his undertakings; for the Lord was with him" [RSV]), that anyone who says David sinned in the case of Bathsheba "is merely erring". 
difficulty with his added indication that David wore the crown "always" (see 7.160; cf. nn. 114, 124).

At the opening of his Antiquities in 1.17 Josephus assures readers that in what follows he will not "add to" or "omit anything from" the Scripture records on which he is basing himself. Ant. 7.147-161, where on the one hand the basic content of 2 Samuel 12 is reproduced even in its details, while on the other additions, deletions, re-arrangements and other modifications of biblical data abound, offers an instructive example of how seriously, but also how flexibly, the historian carried through on that opening promise.

\section{Consulted literature}

Abegg, M Jr., et al. 1999. The Dead Sea Scrolls Bible. San Francisco.

Anderson, A A 1989. 2 Samuel [Dallas 1989], ad loc.)?

Barthélemy, D 1963. Les devanciers d'Aquila. Leiden.

Begg, C T 1993. Josephus’ Account of the Early Divided Monarchy. Leuven.

-, 1996. "The Rape of Tamar (2 Samuel 13) according to Josephus", Estudios Bíblicos 54 (1996) 465-500.

Brooke, A E MacLean N and Thackeray H St J (eds.), 1927. The Old Testament in Greek according to the Text of Codex Vaticanus, II:I, I and II Samuel. Cambridge.

Dietrich, E K 1998. Die Umkehr (Bekehrung und Busse) im Alten Testament und in Judentum. Stuttgart.

Feldman, L H 1998a. Studies in JosephuS’ Rewritten Bible. Leiden.

-, 1998b. Josephus' Interpretation of the Bible. Berkeley, CA.

Finke (ed.), A 2001. The Samuel Scroll from Qumran. Leiden.

Gnuse, R K 1996. Dreams and Dream Reports of Josephus. Leiden.

Gryson R (ed.) 1994. Biblia sacra iuxta vulgatam versionem. Stuttgart.

Harrington, D J and Saldarini, A J 1987. Targum Jonathan of the Former Prophets Wilmington, DE.

Harvey, G 1996. The True Israel: Uses of the Names Jew, Hebrew and Israel in Ancient Jewish and Early Christian Literature. Leiden.

Marcos, N F and Saiz B J R (eds) 1989. El Texto Antiqueno de la Biblia Griega, I, 1-2 Samuel. Madrid.

Marcus, R 1934. Josephus, V. Cambridge, MA/London.

McIvor, J S 1994. The Targum of Chronicles. Collegeville, MN ad loc.

Niese, B 1955. Flavii Josephi Opera. II, Berlin. 
Nodet, E 2001. Flavius Josèphe, III, Les Antiquités Juives Livres VI et VII. Paris.

Nutkowicz, H 2004. "Propos autour de la mort d'un enfant: 2 Samuel $x_{2}{ }_{2}$ xii $_{24}$ ", VT 54 (2004) 104-18.

O'Ceallaigh, G C 1962. “And So David Did To All the Cities of Ammon”, VT 12 (1962) 179-189.

Rappaport, S 1930. Agada und Exegese bei Flavius Josephus. Wien.

Rodríguez, C M (ed.), 1989. Glosas Marginales de Vetus Latina en las Biblias Vulgatas Españolas, I, 1-2 Samuel. Madrid.

Schlatter, A 1932. Die Theologie von Judentum nach dem Bericht von Josephus. Gütersloh.

Sabatier, P (ed.) 1751, Biblia Sacrorum Latinae Versiones Antiquae seu Vetus Italica, I:II. Paris.

Shutt, R H 1980. "The Concept of God in the Works of Flavius Josephus", JJS 31 (1980), 171-189.

Sperber, A (ed.), 1959. The Bible in Aramaic, II. Leiden.

Ulrich, E C 1989. "Josephus' Biblical Text for the Books of Samuel”, in: Feldman, L H and Hata, G (eds.), Josephus, the Bible and History. Detroit.

Wojcik, J 1980. "Descriminations against David's Tragedy in Ancient Jewish and Christian Literature", in: Frontain, R-J and Wojcik, J (eds.), The David Myth in Western Literature.West Lafayette, IN 1980, 13-35. 